\title{
Hydrologic sensitivity of flood runoff and inundation: 2011 Thailand floods in the Chao Phraya River basin
}

\author{
T. Sayama ${ }^{1, a}$, Y. Tatebe ${ }^{1, b}$, Y. Iwami ${ }^{1}$, and S. Tanaka ${ }^{1, a}$ \\ ${ }^{1}$ International Centre for Water Hazard and Risk Management, Public Works Research Institute, Tsukuba, Japan \\ ${ }^{a}$ now at: Disaster Prevention Research Institute, Kyoto University, Uji, Japan \\ ${ }^{\mathrm{b}}$ now at: CTI Engineering, Co. Ltd., Tokyo, Japan \\ Correspondence to: T. Sayama (sayama.takahiro.3u@kyoto-u.ac.jp)
}

Received: 29 October 2014 - Published in Nat. Hazards Earth Syst. Sci. Discuss.: 19 November 2014

Revised: 17 June 2015 - Accepted: 21 June 2015 - Published: 24 July 2015

\begin{abstract}
The Thailand floods in 2011 caused unprecedented economic damage in the Chao Phraya River basin. To diagnose the flood hazard characteristics, this study analyses the hydrologic sensitivity of flood runoff and inundation to rainfall. The motivation is to address why the seemingly insignificant monsoon rainfall, or 1.2 times more rainfall than for past large floods, including the ones in 1995 and 2006, resulted in such devastating flooding. To quantify the hydrologic sensitivity, this study simulated longterm rainfall-runoff and inundation for the entire river basin $\left(160000 \mathrm{~km}^{2}\right)$. The simulation suggested that the flood inundation volume was 1.6 times more in 2011 than for the past flood events. Furthermore, the elasticity index suggested that a $1 \%$ increase in rainfall causes a $2.3 \%$ increase in runoff and a $4.2 \%$ increase in flood inundation. This study highlights the importance of sensitivity quantification for a better understanding of flood hazard characteristics; the presented basin-wide rainfall-runoff-inundation simulation was an effective approach to analyse the sensitivity of flood runoff and inundation at the river basin scale.
\end{abstract}

\section{Introduction}

The 2011 large-scale floods over the Chao Phraya River basin resulted in the worst ever economic flood damage to Thailand (The World Bank, 2012). The flooding appeared to be induced mainly by rainfall from five typhoons and tropical depressions between May and October. The total rainfall in the 6 months during the monsoon season was approximately $1400 \mathrm{~mm}$, while previous large-scale floods were caused by a total rainfall of approximately $1200 \mathrm{~mm}$. The average monsoon-season rainfall in this region is about $1000 \mathrm{~mm}$. Therefore estimating how the additional $200 \mathrm{~mm}$ of rainfall magnifies the runoff and flood inundation is essential to understand the flood characteristics in this basin.

Oldenborgh et al. (2012) analysed a long-term rainfall pattern in the region with the Global Precipitation Climatology Centre (GPCC) V5 product. Based on the analysis, they concluded that the 2011 monsoon rainfall was not very unusual from a viewpoint of large-scale meteorology. Instead they stressed that the main causes of the unprecedented flood damage lay in non-meteorological factors, including reservoir management and conversion of agricultural land into industrial complexes. On the other hand, Komori et al. (2012) highlighted the fact that the seemingly insignificant rainfall may contribute significantly to the increase in runoff volume in the Chao Phraya River basin. They conceptually explained that the 1.4 times more rainfall than normal years might result in 2.5 times more runoff than normal years under a constant evapotranspiration assumption. Kotsuki and Tanaka (2013) performed a hydrologic simulation with a land surface model and concluded also that runoff is highly sensitive to rainfall (2.25 times more than average) in a naturalized condition excluding dam effects.

These studies are in line with hydrologic sensitivity analyses. Schaake (1990) introduced an elasticity index to quantify the runoff change to precipitation change as Eq. (1).

$\varepsilon_{Q}=\frac{\mathrm{d} Q / Q}{\mathrm{~d} P / P}=\frac{\mathrm{d} Q}{\mathrm{~d} P} \frac{P}{Q}$

The elasticity $\varepsilon_{Q}$ represents how much runoff is expected to change, in percentage terms, with a $1 \%$ change in rain- 
fall. Schaake (1990) used a watershed hydrologic model with varying rainfall and temperature to estimate the elasticity of runoff. He found the elasticity is generally higher in drier conditions than wetter conditions. Dooge (1992) and Dooge et al. (1999) analytically derived the elasticity based on a Budyko-type formula, and demonstrated the impact of seasonality and different climate conditions. Sankarasubramanian et al. (2001) summarized the five approaches of hydrologic sensitivity analysis including a regression model-based approach with historic records (Risbey and Entekhabi, 1996) and a simulation model-based approach with perturbed input variables (e.g. Vano et al., 2012; Mizukami et al., 2014; Vano and Lettenmaier, 2014). One of the advantages of the model-based approach is the ability to evaluate not only annual runoff but monthly or daily runoff variations. In fact, Schaake (1990) evaluated the monthly peak runoff to surrogate for the annual maximum flood in the elasticity estimation. However, to the authors' best knowledge, none of the previous studies have estimated the elasticity of flood inundation, which is more directly related to the impact of floods in river basins with large delta areas (Dutta et al., 2003; Apel et al., 2006).

A possible reason for the lack of study on inundation elasticity may be associated with the difficulty in the quantification of flood inundation volume, especially for the long term in large river basins. Most of the existing inundation models are only applied to floodplains and constrained by boundary conditions of upstream river discharges or inflow to the floodplains. Those boundary conditions are generally difficult to define if multiple locations are inundated in a large river basin. Taking multiple inundations at various locations and their interactions in large river basins into account, this study employs a rainfall-runoff-inundation (RRI) model (Sayama et al., 2012). The model simultaneously simulates rainfall-runoff and flood inundation processes on a 2-D basis at a river basin scale. Since these two processes interact with each other, the concept of the RRI model with rainfall forcing is thought to be suitable to estimate the elasticity of runoff and flood inundation.

The objective of this study is to quantify the sensitivity of flood runoff and inundation volumes to diagnose the characteristics of the 2011 Thailand floods. We first calibrate the RRI model based on river discharge and test the inundation simulation result using remote sensing as well as the peak inundation water depths of 2011. Then we run the model continuously for 52 years (1960-2011) without the effect of dams and for 32 years (1980-2011) with the effect of two major dams. Based on the simulation results, we analysed the relationship among rainfall, runoff and inundation volumes for different years, including 2011 for the entire Chao Phraya River basin. Finally, we applied a regression model to the simulated historic runoff and inundation to estimate their elasticity indices.

\section{Study area}

The Chao Phraya River drains from an area of $160000 \mathrm{~km}^{2}$ from northern Thailand to the gulf of Thailand (Fig. 1). There are four major tributaries, i.e. Ping, Wang, Yom and Nan, flowing from the northern mountainous regions to the central point at Nakhon Sawan city. Upstream and downstream of Nakhon Sawan is a widespread lowland area, of which longitudinal gradient is approximately $1 / 12000$. The river section between Ayutthaya and Bangkok is even milder with a gradient of about $1 / 50000$. The bankfull discharges are about $3000-4000 \mathrm{~m}^{3} \mathrm{~s}^{-1}$ at Nakhon Sawan, about 2200$2900 \mathrm{~m}^{3} \mathrm{~s}^{-1}$ upstream and downstream of Ayutthaya (the main river is only about $1300 \mathrm{~m}^{3} \mathrm{~s}^{-1}$ at Ayutthaya after the diversion) and about $3600 \mathrm{~m}^{3} \mathrm{~s}^{-1}$ in Bangkok (Vongvisessomjai, 2007). In the Chao Phraya River basin, there are two major dam reservoirs, the Bhumibol dam $\left(13.5\right.$ billion $\mathrm{m}^{3}$, in operation since 1964) located in the Ping River and the Sirikit dam (9.5 billion $\mathrm{m}^{3}$, in operation since 1974) located in the Nan River. The primary purposes of the dam reservoirs are water resources and power generation.

The climate of the area is characterized by tropical monsoon. Average annual rainfall is between 1000 and $1400 \mathrm{~mm}$ and $85 \%$ of the total rainfall occurs in April to October. In addition to the frontal rain from the monsoon, the basin receives rainfall from typhoons or tropical low depressions from the northern Pacific Ocean (JICA, 2013).

In 2011, five typhoons and tropical depressions hit the northern part of the basin. As a result, approximately $1400 \mathrm{~mm}$ of rainfall fell in the wet season. The Bhumibol and Sirikit dam reservoirs were $45 \%$ filled and $51 \%$ filled by 15 April 2011, respectively, and then both were $95 \%$ filled by 5 October and 14 September 2011 (Komori et al., 2013; Mateo et al., 2014). The peak discharge at Nakhon Sawan was $4686 \mathrm{~m}^{3} \mathrm{~s}^{-1}$ on 14 October 2011. The overtopped river flow and additional rainfall in the delta submerged seven industrial parks near Ayutthaya and the northern and western parts of Bangkok, whose central business district barely escaped the severe flooding. The damage was devastating, with economic damage and loss of USD 46.5 billion.

\section{Method}

This section explains the overview of the RRI model and its application to the Chao Phraya River basin, followed by the elasticity estimation method adopted in this study.

\subsection{Structure of the rainfall-runoff-inundation model}

The RRI model is a 2-D model capable of simultaneously simulating rainfall-runoff and flood inundation (Fig. 2) (Sayama et al., 2012). The model deals with land and river channels separately. In a grid cell where a river channel is located, the model assumes that both land and river are positioned within the same grid cell. The channel is discretized 


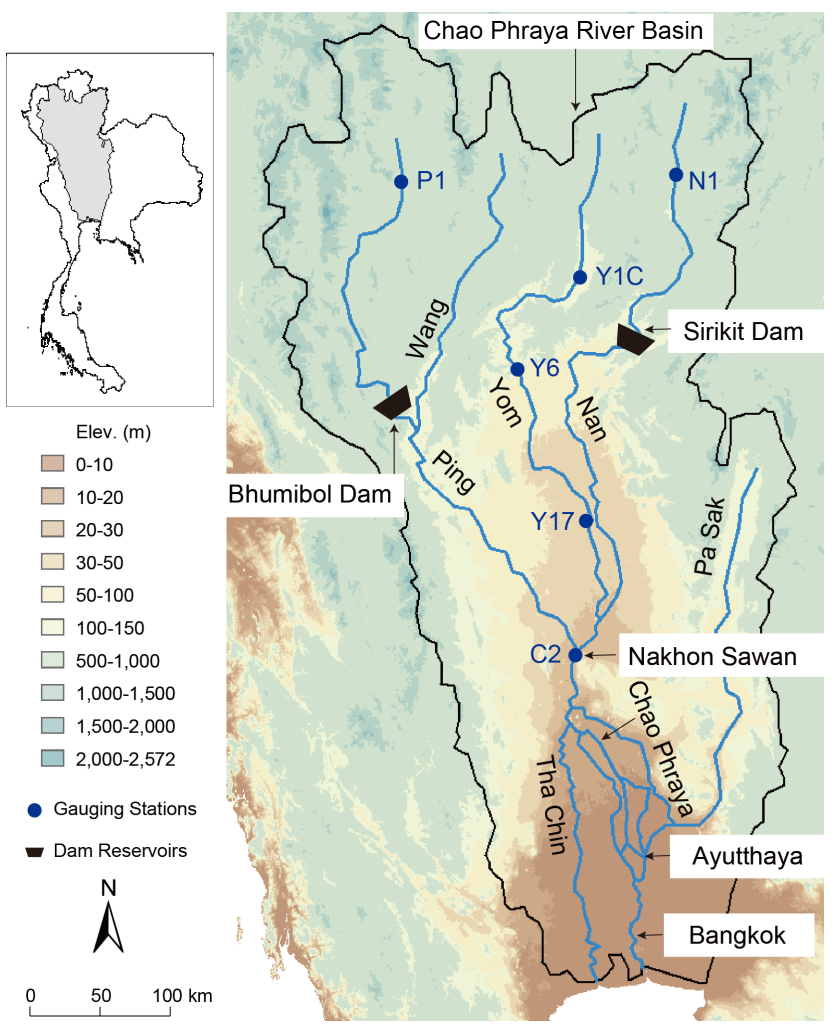

Figure 1. Map of the Chao Phraya River basin, Thailand.

as a single line along its centerline of the overlying slope grid cell. The flow on the land grid cells is calculated with the 2D diffusive wave model, while the channel flow is calculated with the 1-D diffusive wave model.

All the land grid cells can receive rainfall and contribute to rainfall-runoff flowing through other land grid cells and river channels. Meanwhile, they are subject to inundation due to multiple causes: overtopping from river channels, expansion of inundation water from surrounding land grid cells, accumulation of local rainwater or any combination of the three. Hence, the RRI model does not structurally distinguish between rainfall-runoff and flood inundation processes; instead, it solves water flow hydrodynamically. In terms of its application to an entire river basin with rainfall input, the model is similar to grid cell-based distributed rainfall-runoff models. While typical rainfall-runoff models fix flow directions at each grid cell based on surface topography, the RRI model changes flow directions dynamically. In this regard, the RRI model resembles 2-D flood inundation models (e.g. Iwasa and Inoue, 1982). Nevertheless, unlike many other flood inundation models, the application of the RRI model is not limited to floodplains. It is applicable to an entire river basin. It simulates flow interactions between land and river channels with considerations of levees, so that the RRI model does not require specifying an overflowing point and its overtopping discharge, which are typically required as boundary

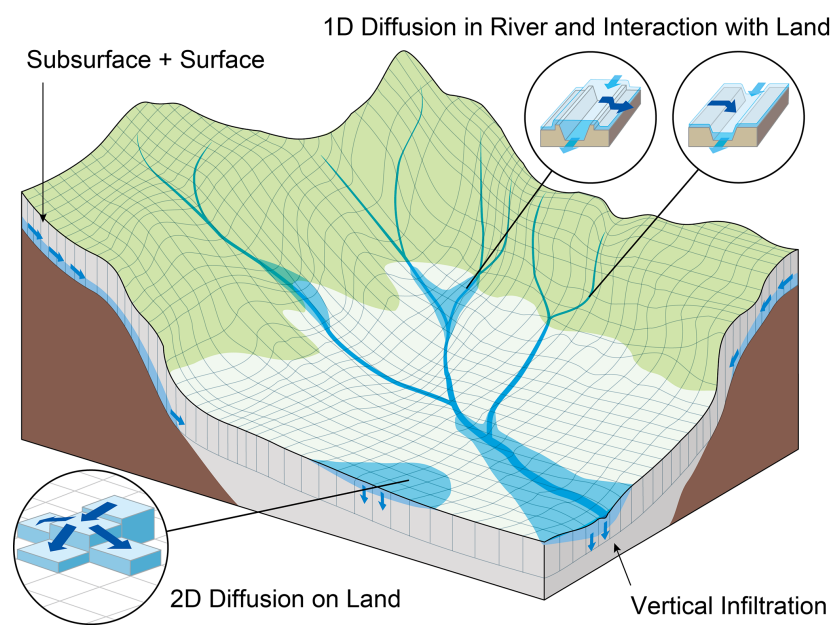

Figure 2. Schematic diagram of the rainfall-runoff-inundation (RRI) model (Sayama et al., 2012).

conditions when using inundation models. Another feature of the RRI model is the acceptance of rainfall and potential evapotranspiration as model input. It estimates actual evapotranspiration based on the soil moisture conditions and simulates surface and subsurface flow processes including flood inundation. The application of an integrated equation for surface and subsurface flows, numerically solved by an adaptive time step Runge-Kutta algorithm (Cash and Karp, 1990; Press et al., 1992), enables the RRI model to run fast and stable calculations, even for a large river basin with mountainous and plain areas.

\subsection{Model application to the Chao Phraya River basin}

The RRI model is applied to the entire Chao Phraya River basin. As the model was being set up, the DEM (digital elevation model), flow direction and flow accumulation were delineated from HydroSHEDS 30 s (Lehner et al., 2008) and upscaled to a $60 \mathrm{~s}$ (approximately $2 \mathrm{~km}$ ) resolution (Masutani et al., 2006). Note that the RRI model uses flow direction and accumulation only to determine river channel locations but not for flood routing, since the flow direction varies depending on local hydraulic gradients. Local river depths $D(\mathrm{~m})$ and widths $W(\mathrm{~m})$ were decided, based on cross-section information at 121 sections, while for tributaries with no crosssection information, we approximated widths and depths using Eqs. (2) and (3) (Coe et al., 2008).

$$
\begin{aligned}
W & =C_{\mathrm{W}} A^{S_{\mathrm{W}}} \\
D & =C_{\mathrm{D}} A^{S_{\mathrm{D}}},
\end{aligned}
$$

where $A$ is the upstream contributing area $\left(\mathrm{km}^{2}\right)$ and $C_{\mathrm{W}}$, $S_{\mathrm{W}}, C_{\mathrm{D}}$ and $S_{\mathrm{D}}$ are regression parameters, whose values were estimated from river cross-section data. The obtained parameters were: $C_{\mathrm{W}}=16.93, S_{\mathrm{W}}=0.186, C_{\mathrm{D}}=2.48$ and $S_{\mathrm{D}}=0.12$. These equations capture the general characteris- 
tics of the river's cross sections becoming wider and deeper towards downstream.

The model input is rainfall and potential evapotranspiration. Daily rainfall records were observed at about 400 stations fairly equally distributed in the whole basin and used after Thiessen polygon interpolation. Potential evapotranspiration was estimated with the Penman-Monthieth equation based on the European Centre for Medium-Range Weather Forecasts (ECMWF) reanalysis (Uppala et al., 2005). The Ecoclimap data set (Tchuente et al., 2010), provided by Meteo France, was also used to identify seasonal and spatial variations of leaf area index.

To set model parameters, the area was first classified into two areas: mountains and plains. The forest area is mainly distributed in upstream mountainous regions, where downslope subsurface flow and surface flow are simulated by taking both surface and subsurface flows into account (see detail in Sayama et al., 2012). On the other hand, the cultivated area including some urban areas is distributed mainly in downstream plain regions, where vertical infiltration and surface flow are simulated with the Green-Ampt (G-A) model.

With respect to the effect of two major dams (Bhumibol and Sirikit), this study conducted two sets of simulation. The first one was a naturalized case, which did not take the dam effects into account, and used as the baseline simulation for water balance analysis. The simulation period for this case was 1960-2011 (52 years). The second case was to simulate water-regulated conditions, which used reservoir outflow records as boundary conditions for the two dam reservoirs. This regulated case was compared with the naturalized one to understand how the dams contributed to reduce flood runoff and inundation. The simulation period for the regulated case was limited to 1980-2011 (32 years) due to the availability of dam release records.

\subsection{Water balance analysis}

Based on the 52-year continuous rainfall-runoff-inundation simulation, we analyse basin-wide water balance for all the monsoon seasons. We calculate spatially averaged rainfall, simulated actual evapotranspiration, runoff, catchment storage and flood inundation. The runoff in this study is defined as all the water volume flowing out from the river basin; i.e. discharge at the mouth of the Chao Phraya River basin as well as some flooded water flowing out directly from the basin into the sea. The catchment water storage is the total volumes of cumulative infiltrated volume within the G-A model, water height equivalent in soil and surface as well as water volume stored in the rivers. If surface water depths exceed $0.5 \mathrm{~m}$ due to accumulation of surface water, the volume of the water on land surface is considered as flood inundation volume and excluded from the catchment storage. Note that total volumes of simulated catchment storage and flood inundation are divided by area of the basin, so that all the wa- ter balance components have the same unit as average water depths in $\mathrm{mm}$.

For the water balance analysis, the selection of period is very important. In this study, since our goal is to assess the relationship between rainfall and flood inundation volume, we first look at a period whose rainfall amount has the highest correlation with the maximum flood inundation volume. More specifically, by setting the maximum flood inundation date as the ending point of the water balance calculation period and changing the duration from 1 to 7 months, we calculated correlation coefficients between rainfall amount during the selected period and the maximum flood inundation volume. For each simulation year, we calculate rainfall $P$, evapotranspiration ET, catchment storage change $\Delta S$, total runoff $Q$ and flood inundation volume change $\Delta F$ in the selected period ending with each year's peak inundation arrival date. Note that $\Delta S$ and $\Delta F$ are used to describe the change in catchment storage and flood inundation volumes from the water balance point of view. However, since the flood inundation at the beginning of the rainy season is negligible, $\Delta F$ can be regarded as the peak flood inundation volume for each year. Based on the water balance, the following equation can be obtained:

$P=\mathrm{ET}+Q+\Delta S+\Delta F$.

\subsection{Elasticity index}

The focus of this study is to understand the relationship between each term of the water balance equation including the flood inundation volume. We primarily focused on the $\mathrm{d} Q / \mathrm{d} P$ and $\mathrm{d} \Delta F / \mathrm{d} P$ to estimate how much runoff and inundation volumes are expected to increase with increase in rainfall in absolute volume. In addition, to represent the sensitivities of runoff to rainfall variability, the elasticity index $\varepsilon_{Q}$ (Eq. 1) is also calculated (Schaake, 1990). Thus the elasticity for flood inundation volume $\varepsilon_{\Delta F}$ can be defined as:

$\varepsilon_{\Delta F}=\frac{\mathrm{d} \Delta F / \Delta F}{\mathrm{~d} P / P}=\frac{\mathrm{d} \Delta F}{\mathrm{~d} P} \frac{P}{\Delta F}$.

Note that the indices contain the term of $\mathrm{d} \Delta F / \mathrm{d} P$ and quantify how much inundation volumes is expected to increase, in percentage terms, with a $1 \%$ increase in rainfall.

To understand the general characteristics of the elasticity index, we exemplify a simple linear model of runoff $Q=a P+b$, where $a$ and $b$ are constants. The model suggests that even if $\mathrm{d} Q / \mathrm{d} P$ is a constant $(=a)$, elasticity $\varepsilon_{Q}$ $(=a P /(a P+b))$ can be dependent on the reference $P$. For a robust estimation of elasticity, Sankarasubramanian et al. (2001) used a nonparametric estimator, in which a longterm mean of $P$ is used as the reference. In the case of elasticity of flood inundation volume $\varepsilon_{\Delta F}$, however, the long-term mean of $P$ may not be suitable because flood inundation volume is nearly zero in a normal year; as a result, $\varepsilon_{\Delta F}$ approaches to infinity. Since our interest here is the sensitivity 
of flood runoff and inundation volumes in flooding situations, we will define a reference $P$ according to the records of past flood events.

\section{Model simulation results}

\subsection{River discharge}

Figure 3 shows simulated and observed monthly discharge. We split the period between 1980 and 2011 into a calibration period (1980-1999) and a validation period (2000-2011). Model parameters were then manually calibrated by focusing on the naturalized monthly discharge, marked at $\mathrm{C} 2$, and evaluated at other upstream locations. The naturalized discharge is estimated to avoid the effect of dams by adding inflow and subtracting outflow from the two major dam reservoirs to the observed monthly discharge. Table 1 shows the calibrated parameters for mountain and plain areas. Note that the following sensitivity analysis covers the period of 1960 2011. However, due to the reliability of observed discharges, we only focused here on 1980-2011 for the model evaluation. We used three metrics including Nash-Sutcliffe efficiency (NSE), coefficient of determination $\left(r^{2}\right)$ and relative volume error (VE) to evaluate the model performance (see Appendix A).

The hydrograph in Fig. 3 shows that the model can reproduce $\mathrm{C} 2$ monthly river discharge well for both calibration and validation periods. The evaluation statistics were $\mathrm{NSE}=0.88, r^{2}=0.89, \mathrm{VE}=0.04$ in the calibration period and NSE $=0.89, r^{2}=0.89, \mathrm{VE}=0.01$ in the validation period. For the other upstream locations, we evaluated monthly river discharges between 1980 and 2011 with the calibrated model (Table 2). Figure 3 shows the observed and simulated hydrographs at selected locations including $\mathrm{N} 1$ and P1. At the N1 location, although NSE and $r^{2}$ were 0.87 and 0.91 , negative VE $(=-0.21)$ indicates the underestimation of total river discharge. The statistics at Sirikit Dam $(\mathrm{NSE}=0.87$, $r^{2}=0.91, \mathrm{VE}=-0.20$ ), located at the downstream of $\mathrm{N} 1$, also show the similar model behaviour. On the other hand, at P1 location, positive VE $(=0.33)$ indicates the overestimation of total river discharge. Hence the model performance varies depending on the tributaries. The performance of Y17 was also low $(\mathrm{NSE}=0.50)$, possibly due to the diversion channel located at the upstream of Y17 to the lower Nan River. Although further model calibration may improve the performance in simulating upstream river discharges, in this study we could not carry out further optimization of model parameters given our computational resources. Instead, we focus on the $\mathrm{C} 2$ location for the calibration since it is the most important point directly related to the flood inundation in the whole basin.
Table 1. Model parameter setting. The entire river basin is categorized into two regions: mountain and plain areas. A type S-S (surface + subsurface) model is applied to the mountain area with parameters related to soil depths $d_{\mathrm{a}}$ and $d_{\mathrm{m}}$, lateral saturated hydraulic conductivity $k_{\mathrm{a}}$ and an exponent parameter $\beta$ related to unsaturated hydraulic conductivity. A type S-I (surface + infiltration) model is applied to the plain area with the G-A model. Their parameters include vertical saturated hydraulic conductivity $k_{\mathrm{v}}$, porosity $\varphi$ and wetting front soil suction head $S_{\mathrm{f}}$, whose values are referred to by Raws et al. (1992). $F_{\text {limit }}$ is an upper limit for the cumulative infiltration depth $F$ in the G-A model. The parameters $n$ and $n_{\text {river }}$ are Manning's roughness coefficients for land surface and river channels. See Sayama et al. (2015) for more details on the equations and their parameters used in the RRI model.

\begin{tabular}{llcc}
\hline \multicolumn{2}{c}{ Parameters } & Mountains & Plains \\
\hline$n$ & $\left(\mathrm{~m}^{-1 / 3} \mathrm{~s}\right)$ & 0.35 & 0.35 \\
$d_{\mathrm{a}}$ & $(\mathrm{m})$ & 3.0 & - \\
$d_{\mathrm{m}}$ & $(\mathrm{m})$ & 1.5 & \\
$k_{\mathrm{a}}$ & $\left(\mathrm{m} \mathrm{s}^{-1}\right)$ & 0.01 & - \\
$\beta$ & $(-)$ & 8.0 & - \\
$k_{\mathrm{V}}$ & $\left(\mathrm{cm} \mathrm{h}^{-1}\right)$ & - & 0.06 \\
$\varphi$ & & - & 0.471 \\
$S_{\mathrm{f}}$ & & - & 0.273 \\
$F_{\text {limit }}$ & $(\mathrm{m})$ & - & 0.4 \\
$n_{\text {river }}$ & $\left(\mathrm{m}^{-1 / 3} \mathrm{~s}\right)$ & \multicolumn{2}{c}{0.03} \\
\hline
\end{tabular}

Table 2. Model performance evaluated by Nash-Sutcliffe efficiency (NSE), coefficient of determination $\left(r^{2}\right)$ and relative volume error (VE) for river discharges (1980-2011) at gauging stations and two dam sites (B. dam: Bhumibol dam, S. dam: Sirikit dam).

\begin{tabular}{lccr}
\hline & NSE & $r^{2}$ & VE \\
\hline C2 & 0.89 & 0.89 & 0.03 \\
N1 & 0.87 & 0.91 & -0.21 \\
P1 & 0.67 & 0.83 & 0.33 \\
Y1C & 0.76 & 0.85 & -0.12 \\
Y6 & 0.83 & 0.85 & 0.02 \\
Y17 & 0.50 & 0.71 & 0.33 \\
B. dam & 0.80 & 0.87 & -0.04 \\
S. dam & 0.87 & 0.91 & -0.20 \\
\hline
\end{tabular}

\subsection{Flood inundation}

We also test the RRI model performance in terms of peak flood inundation extent. Figure 4 shows the simulated annual maximum flood inundation depths (upper panel) and remote sensing composites (lower panel). For 2011, we referenced information released by UNITAR's Operational Satellite Applications Programme (UNOSAT), which used multiple-satellite information for estimating the maximum flood extent of the 2011 flood event in Thailand. For previous years for which no UNOSAT information is available, we used composite images produced by the Geo-Informatics 

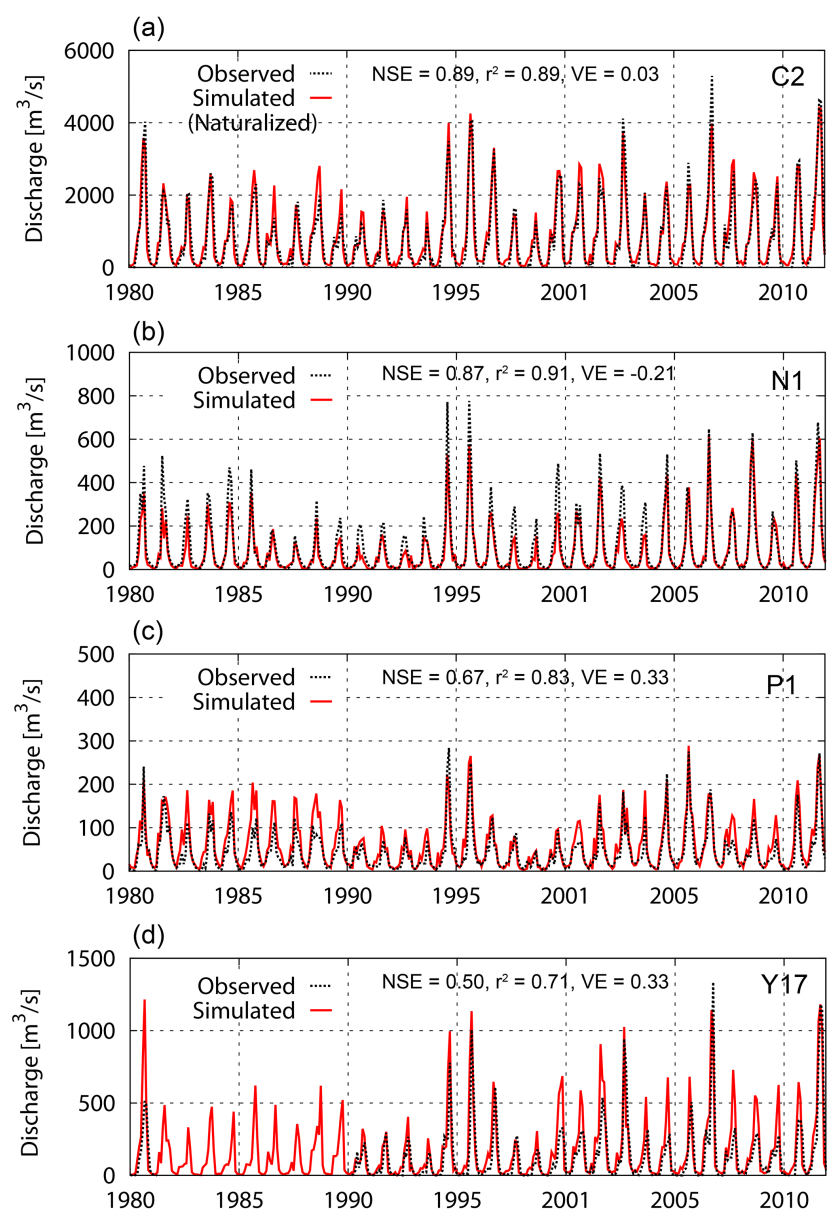

Figure 3. Simulated and observed monthly averaged river discharges at (a) C2 (naturalized), (b) N1, (c) P1 and (d) Y17 (observed records were not available between April 1981 and March 1990 at Y17). Note that $\mathrm{C} 2$ discharges are naturalized by excluding the effect of the two dams, while N1 and P1 are located upstream of the dams and Y17 at a different tributary. The model performance is evaluated by NSE, $r^{2}$ and VE for the period of 1980-2011.

and Space Technology Development Agency (GISTDA) in Thailand.

For 2011, Fig. 4 shows that the model tends to underestimate inundation extent identified by remote sensing, especially upstream of the $\mathrm{C} 2$ location. According to the evaluation statistics defined in Appendix A, 57\% of the remote sensing inundation extent was identified by the RRI model (i.e. the hit ratio was 0.57 ) and $72 \%$ of the simulated inundation extent agreed with the remote sensing (i.e. the true ratio was 0.72 ) in 2011 (see Table 3). In addition, the negative normalized error $(\mathrm{NE}=0.21)$ also suggests the model underestimation of the maximum flood inundation extent compared to the remote sensing. The possible reasons for this underestimation include that the remote sensing analysis may judge areas as flooded even when they have shallow water depths, for example in paddy fields. On the other hand, the model
Table 3. Model performance of flood inundation extent and area compared with remote sensing. TR is the true ratio, HR is the hit ratio and NE is the normalized error (see Appendix A for their definitions).

\begin{tabular}{lccr}
\hline & TR & HR & NE \\
\hline 2005 & 0.17 & 0.14 & -0.19 \\
2006 & 0.68 & 0.36 & -0.47 \\
2007 & 0.23 & 0.27 & 0.18 \\
2008 & 0.27 & 0.26 & -0.05 \\
2009 & 0.21 & 0.21 & -0.01 \\
2010 & 0.61 & 0.29 & -0.52 \\
2011 & 0.72 & 0.57 & -0.21 \\
Avg. & 0.41 & 0.30 & -0.18 \\
\hline
\end{tabular}

analysis requires that a threshold of water depth is set to distinguish flood inundation from the temporal ponding of rain water. In this study we used $0.5 \mathrm{~m}$ as the threshold to follow the previous study (Sayama et al., 2012, 2015) since a water level deeper than that may cause severe damages with above-floor flooding (Okada et al., 2011). The other possible reason for the underestimation is that in actual situations, in areas with relatively shallow water flooding, water tends to be stagnant due to roads and paddy field ridges, while in the model, water moves more smoothly because of the resolution; and therefore the model tends to underestimate the flood inundation extent in fringed areas (Sayama et al., 2015).

According to the lower panels in Fig. 4, the basin also suffered severe flood inundation in the years 2006 and 2010. For these 2 years also, the figure shows model underestimation similar to the case in 2011. The underestimation, which is confirmed by low HR values (0.36 in 2006 and 0.29 in 2010) and negative NE values (-0.47 in 2006 and -0.52 in 2010), may be associated with the same reasons as discussed above. Furthermore, the referenced remote sensing also includes uncertainty in the estimation of flood inundation extents. For example, our comparison between UNOSAT and GISTDA for 2011 suggested that GISTDA calculated about 1.5 times larger flood extent compared to UNOSAT. Although we used UNOSAT for 2011, as our field survey confirmed reasonable estimations, for the other previous years, only GISTDA information was available as a source of published data.

For the other years, including 2005, 2007, 2008 and 2009, which have relatively small inundation extents, simulating perfect flood inundation extent is even more difficult. Both the TR and HR are as low as $0.14 \sim 0.27$ in these 4 years. Nevertheless, comparatively small NE values ranging between -0.19 and 0.18 suggest smaller biases in estimating the total area of inundation.

In summary, our comparison between the modelled and remotely sensed inundation extents indicates that the model, compared to remote sensing, tends to underestimate the inundation area, especially in severe flood years, whereas in the other normal years, although the model performs poorly in 


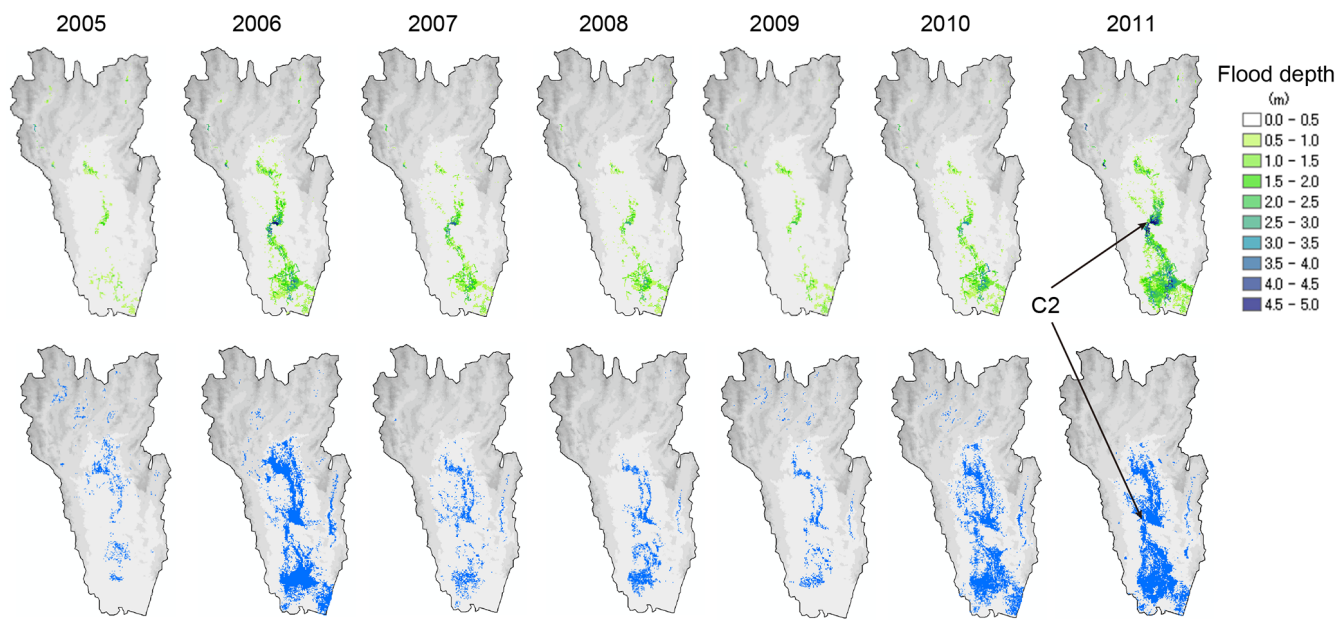

Figure 4. Simulated (upper panel) and remotely sensed (lower panel) annual maximum flood inundation extents from 2005 to 2011 . The source of the remote sensed extents is GISTDA for 2005-2010 and UNOSAT for 2011.

representing exact locations of flood inundation, it performs fairly well in estimating the total area of inundation.

To assess the model performance of peak inundation levels, we also conducted a post-flood field survey in 2011 (Sayama et al., 2015). We used a high-specification GPS and handheld laser telemeter to measure flood marks at 18 points along rivers and 23 points on the floodplains. The average mean error and root mean square error were -0.1 and $0.7 \mathrm{~m}$ along the rivers, while they were 1.1 and $1.2 \mathrm{~m}$ on floodplains. Unlike the inundation extent discussed above, the model showed overestimation in the simulated water depth. This may be related to the accuracy of the satellite-based topographic data. One metre precision of the original HydroSHEDS data and other artifacts including undulation in the satellite-based DEM may limit wide spreading of inundation water (i.e. underestimation of the flood extent), which in turn results in the overestimation of inundation water depths (Tarekegn and Sayama, 2013).

Although we acknowledge that the RRI model when applied to the entire Chao Phraya River basin contains the above mentioned uncertainty, the inundation volume estimations are also constrained by the water balance; i.e. river discharge at $\mathrm{C} 2$ points is reasonably approximated with local rainfall information and evaporation estimates. Based on model performance checking, we further applied the model for the sensitivity analysis of flood runoff and inundation volumes described in the following section.

\section{Sensitivity of flood runoff and inundation}

\subsection{Water balance analysis based on long-term RRI simulation}

After the model was set up, we ran the model for 52 years from 1960 to 2011. The simulation results were then anal- ysed to estimate all the water balance components described in Sect. 3.3. Figure 5 shows the daily values of cumulative rainfall, cumulative actual evapotranspiration, catchment storage, cumulative runoff and flood inundation, respectively. The solid red line shows the 2011 result, while the other grey thin lines show the results from the remaining 51 years. The average values are shown by the solid black lines. In general, the cumulative rainfall, cumulative runoff and flood inundation in 2011 are higher than in other years. The effect of early monsoon rainfall in March 2011 is remarkable $(93 \mathrm{~mm}$ ) compared with the average year $(27 \mathrm{~mm})$. As a result, the catchment water storage also shows rapid increase in March 2011, though the storage in January and February was close to the average. The estimated minimum and maximum catchment water storage in 2011 was about 500 and $1000 \mathrm{~mm}$, respectively, while they were about 400 and $800 \mathrm{~mm}$ in the average year. The high catchment storage volume, together with the additional rainfall during the rainy season, caused inundation starting from as early as June and July, when other years still do not show significant flood inundation. Regarding the seasonal variations in ET, Tanaka et al. (2008) reported that tropical evergreen forest in the mountainous area of the Chao Phraya river basin has a deep soil layer $(\sim 5.3 \mathrm{~m})$, which allows fairly steady evaporation throughout a year regardless of the amount of rainfall in different seasons and years (e.g. Tanaka et al., 2003), whereas for diverse land use in northern Thailand, Kim et al. (2014) reported that ET becomes higher in the monsoon season than in the dry season with about $10 \%$ interannual variations. Essentially the model behaves in a similar way; i.e. water stored in the soil layer during wet seasons is used for evaporation in dry seasons in forest areas with a thick soil layer, and actual ET is limited by soil moisture in plain areas. In general, the estimated variations in actual ET were comparatively smaller than other water balance components. 

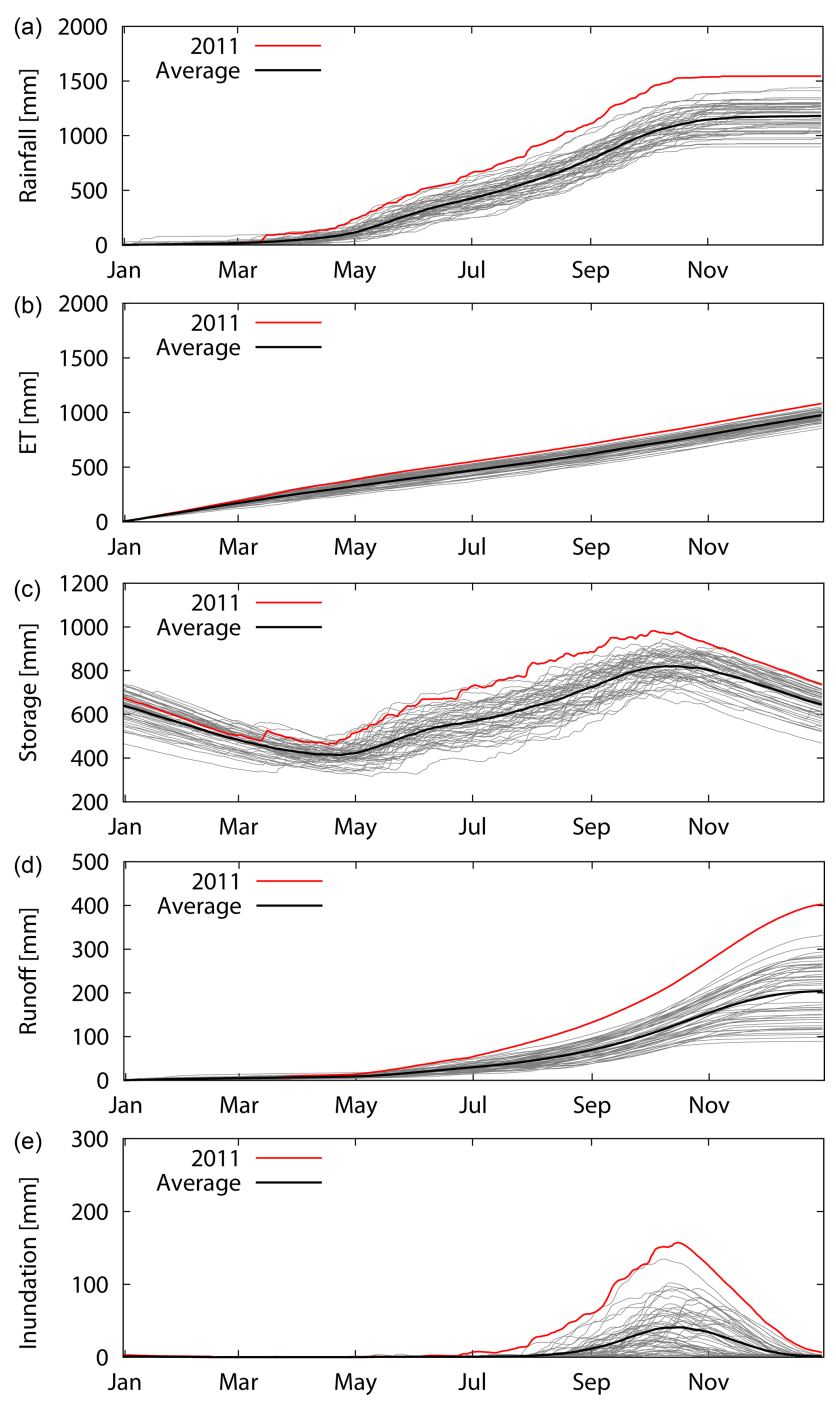

Figure 5. Simulated water balance components for 2011 (red lines), the other 51 years (grey lines) and average values (black lines) in 1960-2011: (a) cumulative rainfall, (b) cumulative evapotranspiration, (c) catchment storage volume, (d) cumulative runoff and (e) inundation volume.

To analyse the relationship between rainfall amounts for different duration and peak inundation volumes, Fig. 6 plots cumulative rainfall counted backwards from the peak inundation of each year ( $x$ axis) and peak inundation volumes ( $y$ axis). Based on the analysis, we found that the 6-month rainfall shows the highest correlation $\left(R^{2}=0.85\right)$ to the peak inundation volumes, so hereafter we use the 6 months as the baseline period for the water balance analysis.

Figure 7 shows the relationship between 6-month rainfall $P$ on the $x$ axis and the other terms including ET, $\Delta S, Q$ and $\Delta F$ at the time of peak inundation on the $y$ axis for all the 52 years without the dams. The figure suggests that ET is almost constant irrespective of $P$, while the other terms tend to increase with the increase in $P$. As for $\Delta F$, it becomes small
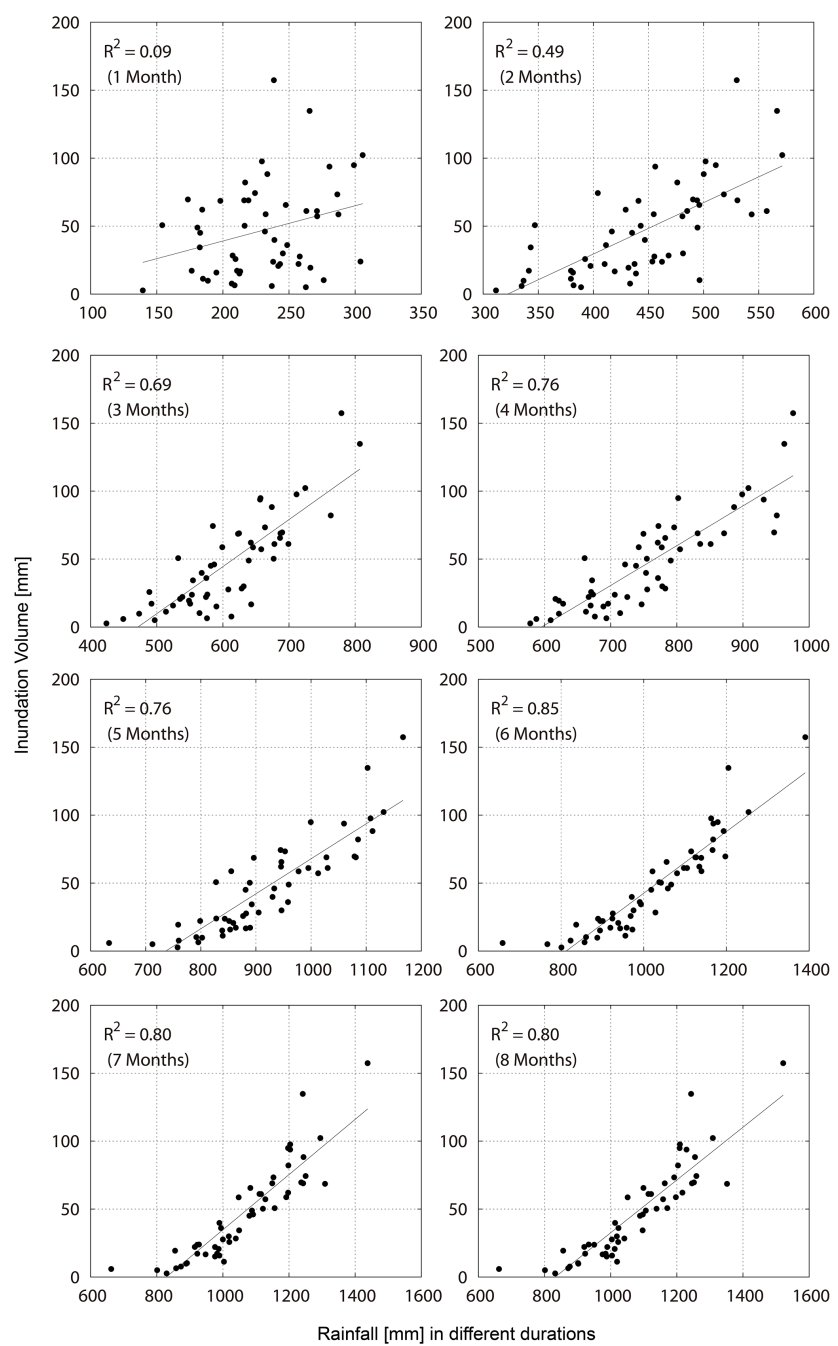

Figure 6. Relationships between annual maximum flood inundation volumes ( $y$ axis) and cumulative rainfall for different durations ( $x$ axis).

$(<30 \mathrm{~mm})$ if $P$ is less than $950 \mathrm{~mm}$, suggesting that no significant flood inundation occurs with less than that amount of rainfall. The slope of $\Delta S(0.41)$ also shows positive correlation with $P$, suggesting the basin stores more water in wetter years than drier years.

\subsection{Elasticity estimations}

The 6-month rainfall was about $1400 \mathrm{~mm}$ in 2011 and about $1200 \mathrm{~mm}$ in past large-scale floods in 1995 and 2002, while the average 6-month rainfall is about $1000 \mathrm{~mm}$ (Fig. 7). In the case of 2011 , the estimated $\Delta F$ was $157 \mathrm{~mm}$, which means that $11 \%$ of the total rainfall turns out contributing to inundation $(\triangle F / P=0.11)$ if no dam reservoirs are taken into account. The figure also suggests that the slope of $\Delta F$ against $P$ can be seen as nearly constant for the range of $P$ greater than $950 \mathrm{~mm}$. The estimated slope $(\mathrm{d} \Delta F / \mathrm{d} P)$ by 


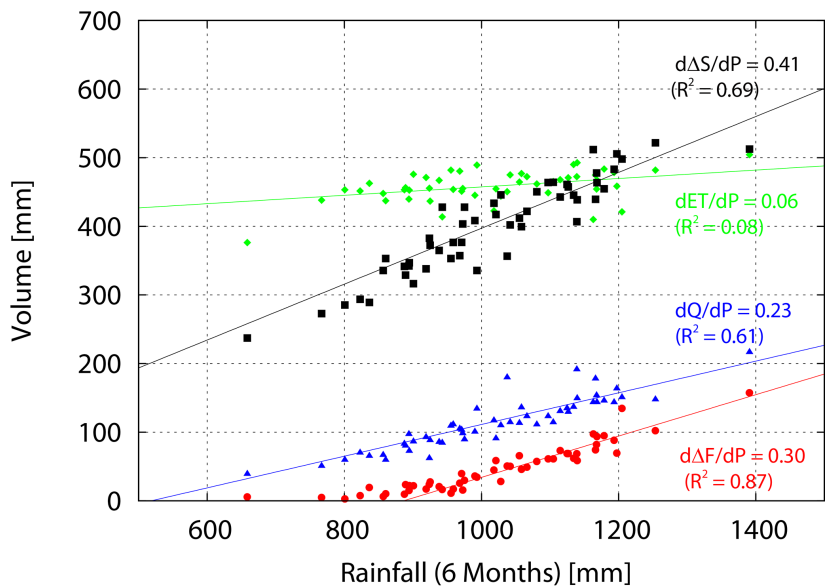

Figure 7. Relationship between cumulative rainfall $(P)$ for 6 months and cumulative evapotranspiration (ET), cumulative runoff $(Q)$, storage change $(\Delta S)$ and inundation volume $(\Delta F)$. Dots show the results from different years based on the 52-year simulation (without the dams).

using a first order linear regression with top 35-year records $(P>950 \mathrm{~mm})$ is 0.30 with $R^{2}=0.87$ (Table 4). Note that $R^{2}$ in Fig. 6 was 0.85, which is different from the value shown in Table 4 because only top 35 -year records were used for the regression analysis in Fig. 7. The figure suggests that an additional $200 \mathrm{~mm}$ rainfall results in a $60 \mathrm{~mm}(=200 \mathrm{~mm} \times 0.30)$ increase in flood inundation volume. Hence the rainfall of $1400 \mathrm{~mm}$ in $2011 \mathrm{might}$ have increased flood inundation volume by about $60 \mathrm{~mm}$, compared with other previous large floods such as 1995 and 2006 under the naturalized condition.

Regarding the runoff component, we need careful interpretation of the figure. As we mentioned above, the ending point of the period for the water balance calculation was set to be at the peak of flood inundation for each year. However, for a better understanding of runoff volume, it is necessary to extend the period to cover flood runoff even after its flood inundation peak. For this purpose, we extended the water balance calculation period for 2 months after its inundation peak, so that the inundated water receded and turned into runoff and other water balance components. As a result, the runoff ratio $\left(Q^{\prime} / P^{\prime}\right)$ of 2011 becomes 0.27 and $\mathrm{d} Q^{\prime} / \mathrm{d} P^{\prime}$ was 0.54 (the dash denotes that the period is extended to 8 months).

In the above discussions, we primarily focused on $\mathrm{d} Q / \mathrm{d} P$ and $\mathrm{d} \Delta F / \mathrm{d} P$ to estimate how much runoff and inundation volumes are expected to increase with increase in rainfall in absolute term. Using these estimated slopes of the regression lines, we can further calculate the elasticity indices defined in Eqs. (1) and (5) since they contain the term of $\mathrm{d} Q / \mathrm{d} P$ or $\mathrm{d} \Delta F / \mathrm{d} P$. As described above, the elasticity depends on the reference $P$. In this study, we will use $P=1200 \mathrm{~mm}$, representing 6-rainfall in past large flood years, as a reference to estimate $\varepsilon_{Q}$ and $\varepsilon_{\Delta F}$ based on the linear regression
Table 4. Parameters of the regression analysis with 6-month cumulative rainfall in Figs. 7 and 8.

\begin{tabular}{lllll}
\hline & & Slope & Intercept & $R^{2}$ \\
\hline No dam & ET & 0.061 & $396.2^{*}$ & 0.08 \\
& $Q$ & $0.231^{*}$ & $-119.6^{*}$ & 0.61 \\
& $\Delta S$ & $0.407^{*}$ & -9.9 & 0.69 \\
& $\Delta F$ & $0.301^{*}$ & $-266.7^{*}$ & 0.87 \\
With dams & $\Delta F$ & $0.249^{*}$ & $-227.2^{*}$ & 0.83 \\
No dam (8 months) & $Q^{\prime}$ & $0.559^{*}$ & $-431.7^{*}$ & 0.71 \\
With dams (8 months) & $Q^{\prime}$ & $0.407^{*}$ & $-274.8^{*}$ & 0.61 \\
\hline
\end{tabular}

$R^{2}$ is the coefficient of determination and asterisk $\left(^{*}\right)$ denotes parameters are identified with $[p<0.01]$.

equations. The estimated $\varepsilon_{Q}$ is 3.0 , whereas the estimated $\varepsilon_{\Delta F}$ becomes 5.0, indicating that a $1 \%$ increase in rainfall may cause more abrupt increases in flood inundation volume $(+5.0 \%)$ than runoff volume $(+3.0 \%)$ in this basin.

\subsection{Effect of dam reservoirs}

The above discussions assume naturalized conditions without considering two major dam reservoirs. Figure $8 \mathrm{a}$ and $\mathrm{b}$ show the effects of the two dams on flood inundation and runoff volumes, respectively. Since the analysis with dams can only be conducted from 1980 due to the dam release records availability, in this figure we plot the results only for the periods without the dams. Figure 8a suggests that the two main dam reservoirs contributed to the reduction of $\Delta F$ by $26 \mathrm{~mm}\left(=4.4\right.$ billion $\left.^{3}\right)$ and also $\mathrm{d} \Delta F / P$ from 11 to $9 \%$. Since the total capacity of the two dam reservoirs on 17 April 2011 (6 months before the peak flood inundation), was $46 \mathrm{~mm}\left(=7.5\right.$ billion $\left.\mathrm{m}^{3}\right)$ and their storages were almost full when the flood inundation reached its peak in mid-October, the $26 \mathrm{~mm}$ out of $46 \mathrm{~mm}$ contributed to the reduction of the flood inundation volume and the rest of the volume was expected to reduce the river discharges. The estimated elasticity of runoff $\varepsilon_{Q}$ is 2.3 , while the estimated elasticity flood inundation volume $\varepsilon_{\Delta F}$ is 4.2 , indicating that a $1 \%$ increase in rainfall may cause more abrupt increases in flood inundation volume $(+4.2 \%)$ than runoff volume $(+2.3 \%)$ with consideration of the two main dam reservoirs.

\subsection{Summary and limitations}

Figure 9 summarizes the results of elasticity estimations with the effects of dam reservoirs. The figure compares three different magnitudes of monsoon rainfall (i.e. 1000, 1200 and $1400 \mathrm{~mm}$ ). In 2011 the runoff is estimated to be $329 \mathrm{~mm}$ (during 8 months), while its runoff in average years is $132 \mathrm{~mm}$. Therefore 1.4 times more rainfall resulted in 2.5 times more runoff compared to average years. The ratio agrees with what has been reported by Komori et al. (2012) as 2.5 times and Kotsuki and Tanaka (2013) as 2.25 times. 

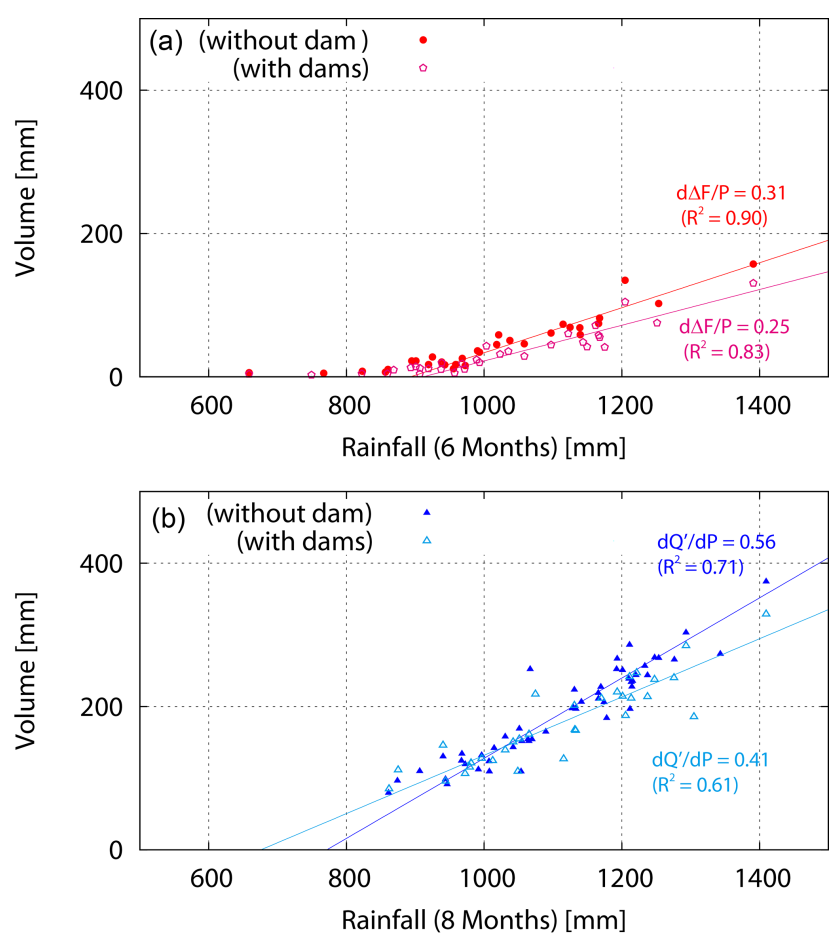

Figure 8. (a) Relationship between cumulative rainfall $(P)$ for 6 months and peak inundation volumes $(\Delta F)$ with and without dams. (b) Relationship cumulative between rainfall $(P)$ for 8 months and cumulative runoff $\left(Q^{\prime}\right)$ with and without dams. Note that for evaluating the cumulative runoff volumes, the period of the analysis was extended by 2 more months after the time of peak flood inundation. Since the figure shows the plots for only between 1980 and 2011 for comparison, the regression result of $\mathrm{d} \Delta F / \mathrm{d} P$ in (a) is different from Fig. 7 and Table 4.

The runoff elasticity $\left(\varepsilon_{Q}\right)$ is estimated to be $2.3 \%$ with the effects of dam reservoirs. The elasticity is within the range (1.0-2.5\%) estimated by Sankarasurbramanian et al. (2001) in the United States. Relatively high runoff elasticity in the reported range may be associated with the fact that moisture (precipitation) and energy (potential evapotranspiration) are "out of phase" for the monsoon climate in Thailand. The seasonality causes high $\varepsilon_{Q}$ in addition to dryness (Dooge et al., 1999).

The main focus of this study was to quantify flood inundation volume and its elasticity. The estimated elasticity for flood inundation $\left(\varepsilon_{\Delta F}\right)$ with dams was $4.2 \%$, which indicates that the inundation is more elastic than the runoff. The reasons for this high elasticity in the flood inundation are two-fold. As Eq. (5) indicates, both $\mathrm{d} \Delta F / \mathrm{d} P$ and $P / \Delta F$ influence the elasticity. The first term $(\mathrm{d} \Delta F / \mathrm{d} P)$ is more important for the sensitivity in absolute volumes, and our analysis in Fig. 8 showed that the slope of the regression line with dams was 0.25 . This means that an additional $200 \mathrm{~mm}$ rainfall increases flood inundation by $50 \mathrm{~mm}$. If we convert this $50 \mathrm{~mm}$ to inundation volume by multiplying it by the area of the river basin, it results in 8.0 billion $\mathrm{m}^{3}$. This value is equivalent to more than $80 \%$ of the second largest dam, namely the Sirikit dam reservoir $\left(9.8\right.$ billion $\left.\mathrm{m}^{3}\right)$. In addition, the second term also tends to be large because flood inundation volume is much smaller compared to total rainfall; in the case of 2011 this study estimated that the $P / \Delta F$ was 16.7 $(=1200 \mathrm{~mm} / 72 \mathrm{~mm})$ with dams. Multiplication of the two terms $(P / \Delta F$ and $\mathrm{d} \Delta F / \mathrm{d} P)$ resulted in the high elasticity $\left(\varepsilon_{F}=4.2 \%\right)$ of the flood inundation volume.

The elasticity estimation presented in this study is the combination of model simulation-based and regressionbased approach. In this approach, we generated synthetic records of flood runoff and inundation from the model simulation and regressed linear lines to estimate the relationship between rainfall and other water balance components. The advantage of this approach is that it avoids assuming artificial spatial and temporal rainfall patterns typically necessary for the synthetic model-based approach. Instead of using historic records of flood inundation, whose direct observation does not exist, we used the RRI model to estimate historic flood runoff and inundation volumes.

In this approach, errors in the simulation can be the main source of the uncertainty in the estimations. The second uncertainty is induced by the deviations from the regression lines shown in Figs. 7 and 8. To reduce the second uncertainty, it is necessary to match the temporal scale of target rainfall suitable for management objectives. This study choose 6 month rainfall prior to the peak of flood inundation as the basis for the analysis (and 2 more months for the total runoff analysis). Another reason for the deviation is due to the linear regression between rainfall and other variables. Although this study employs the linear regression because of its simplicity and robustness within the range of historic rainfall, linear regression may be inadequate for analysing unprecedented extreme events in the future.

The deviations from the regression line in Figs. 7 and 8 indicate that flooding cannot be simply quantified only with 6month rainfall. For example, a spatially and temporally concentrated rainfall pattern with wet antecedent conditions signifies runoff and inundation compared to other cases with a similar magnitude of rainfall. In that case, the plot may be above the linear regression line. To consider the natural variability, the presented approach used a hydrologichydrodynamic model, then analysed the results for sensitivity estimations.

Furthermore, as pointed out by Sankarasubramanian (2001), it is important to employ multiple hydrologic models and parameters to evaluate the sensitivity since each model and its parameters can respond differently to different input. Unfortunately this study could not conduct such multiple simulations with different models because running long-term and large-scale inundation simulations are still computationally expensive. In future research, it will be important to evaluate the elasticity with different models and their parameters. 


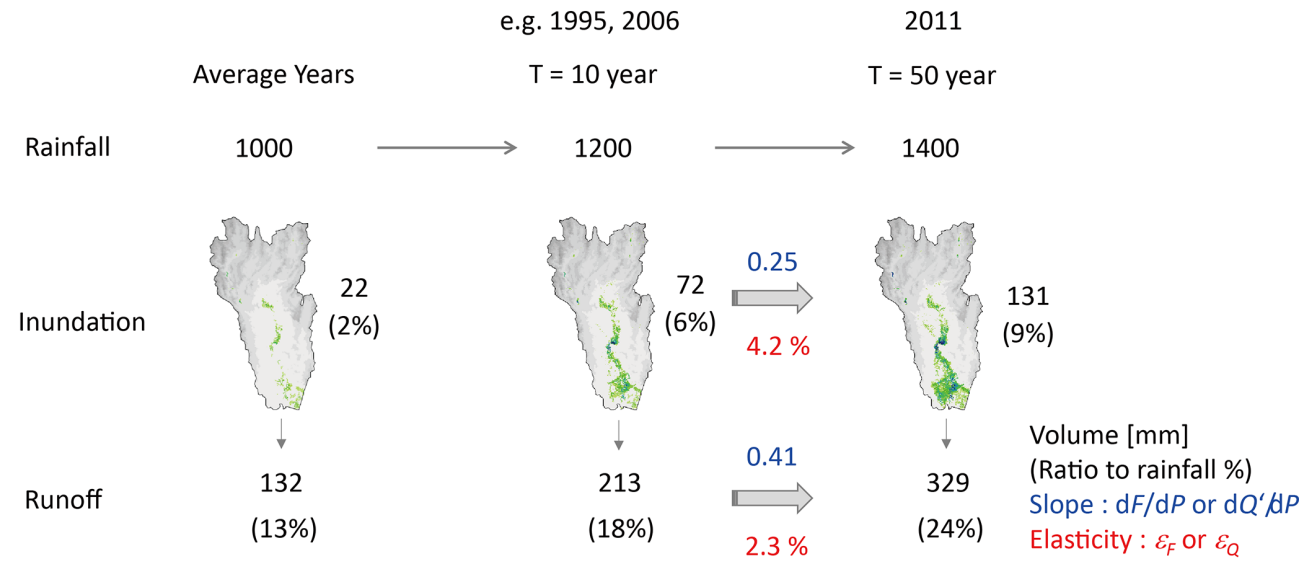

Figure 9. Summary sensitivity analysis of flood runoff and inundation volumes with the effects of dams.

Regardless of all the possible uncertainty described above, our main target of this study was to provide the first-order estimations of water balance components and their elasticity, which helps to quantify how much rainfall turns into flood runoff and inundation volumes in the region for better flood risk management.

\section{Conclusions}

This study estimated the elasticity of flood runoff and inundation in the Chao Phraya River basin. Due to the flat topography with comparatively small bankfull river drainage, the delta suffers from frequent flood inundations. In this kind of environment, estimations of flood runoff and inundation and their sensitivities are essential for better flood risk management. The objective of this study was to quantify the sensitivity of flood runoff and inundation to address why the 2011 Thailand flood became so catastrophic with 1.2 times more or an additional $200 \mathrm{~mm}$ rainfall than for past large floods including the ones in 1995 and 2006.

Our analysis suggested that inundation volumes in this basin have the highest correlation with rainfall amount in the previous 6 months. In the case of 2011, the basin received about $1400 \mathrm{~mm}$ of rainfall in the rainy season, and $9 \%$ of the total rainfall flooded at the peak of inundation with the dam operations. The elasticity of flood inundation volume to rainfall $\varepsilon_{Q}$ was estimated as $4.2 \%$, which is higher than that of the runoff volume $(2.3 \%)$.

The analysis shows two important implications for flood management. The first one is for the diagnostic analysis of flood events. In the case of the 2011 flood, dam operations and other diversion channel management were claimed to be primary causes of the devastating disaster. Seemingly small rainfall variability (i.e. $200 \mathrm{~mm}$ in 6 months) compared to past experienced flood events in the region tends to draw less attention to the magnitude of the event itself. However, our analysis suggested that the flood inundation volume was about 1.6 times $(=329 \mathrm{~mm} / 213 \mathrm{~mm})$ more than past events Ignoring the amount misinterprets the dominant cause of flooding and thus may misguide future management policy. It is essential in the diagnostic analysis of flood disasters to quantify water balance by calculating the process of rainfall to runoff and inundation.

The second implication is for climate change impact assessment. The analysis indicated the high sensitivity of flood inundation volume to rainfall variability in this basin. The presented $\mathrm{d} \Delta F / \mathrm{d} P$ value, together with $\mathrm{d} Q / \mathrm{d} P$ provides a first-order estimation in terms of how the change in total amount of rainfall in rainy seasons affected flooding in the basin. On the other hand, the use of estimated sensitivities requires careful attention of the assumptions and limitations. For example, the effect of temperature change is not represented in the regression between rainfall and flood runoff and inundation volumes. Moreover, we estimated the elasticity based on current land use conditions, whose change also impacts hydrology and flooding. Therefore, for a detailed analysis, the rainfall-runoff-inundation simulations presented in this manuscript can be an effective way for analysing flooding in large river basins. Overall, the proposed method helps us to diagnose simulated and observed hydrologic variables including flood runoff and inundation volumes in terms of their sensitivity to climate conditions. 


\section{Appendix A: Performance measures used in this study}

To evaluate the model performance with respect to simulated discharge against observed discharge, we used the following three metrics.

- Nash-Sutcliffe model efficiency (NSE):

$$
\mathrm{NSE}=1-\frac{\sum\left(Q_{\mathrm{sim}}(t)-Q_{\mathrm{obs}}(t)\right)^{2}}{\sum\left(Q_{\mathrm{obs}}(t)-\overline{Q_{\mathrm{obs}}}\right)^{2}} .
$$

- Coefficient of determination (squared correlation coefficient) $\left(r^{2}\right)$ :

$$
r^{2}=\frac{\sum\left(\left(Q_{\mathrm{sim}}(t)-\overline{Q_{\mathrm{sim}}}\right)\left(Q_{\mathrm{obs}}(t)-\overline{Q_{\mathrm{obs}}}\right)\right)^{2}}{\sum\left(Q_{\mathrm{sim}}(t)-\overline{Q_{\mathrm{sim}}}\right)^{2} \sum\left(Q_{\mathrm{obs}}(t)-\overline{Q_{\mathrm{obs}}}\right)^{2}} .
$$

- Relative volume error (VE):

$$
\mathrm{VE}=\frac{\sum Q_{\text {sim }}(t)-\sum Q_{\mathrm{obs}}(t)}{\sum Q_{\mathrm{obs}}(t)}
$$

where $Q_{\text {sim }}(t)$ and $Q_{\text {obs }}(t)$ are simulated and observed discharge at time step $t$ and $\overline{Q_{\text {obs }}}$ is average observed discharge in time. NSE is a composite measure of bias and random errors; the value is 1 for perfect prediction and 0 if the prediction is no better than the average, and negative for worse than the average. $r^{2}$ is a measure of random errors after scaling with a linear relationship; the value is 1 for perfect positive association and 0 if there is no linear correlation. VE is a measure of relative volume errors and the value is 0 for perfect volume agreement while positive (negative) means over(under-) estimation of volume by a model.
To evaluate the model performance for flood inundation extents, we used the following three indices including True Ratio (TR), hit ratio (HR) and normalized error (NE) of flood inundation area and defined as follows:

$$
\begin{aligned}
& \mathrm{TR}=\frac{\mathrm{IA}_{\mathrm{obs}} \cap \mathrm{IA}_{\text {sim }}}{\mathrm{IA}_{\text {sim }}}, \\
& \mathrm{HR}=\frac{\mathrm{IA}_{\mathrm{obs}} \cap \mathrm{IA}_{\text {sim }}}{\mathrm{IA}_{\mathrm{obs}}}, \\
& \mathrm{NE}=\frac{A_{\text {sim }}-A_{\mathrm{obs}}}{A_{\mathrm{obs}}},
\end{aligned}
$$

where $\mathrm{IA}_{\text {sim }}$ and $\mathrm{IA}_{\mathrm{obs}}$ are flood inundation extents estimated by the simulation and remote sensing, and $A_{\text {sim }}$ and $A_{\text {obs }}$ are the areas of flood inundation extents estimated by the simulation and remote sensing. If both estimations overlap the area perfectly, both TR and HR become 1 and NE becomes 0 . TR evaluates how much of the simulated extent agrees with the remote sensing. HR evaluates how much of the remote sensing extent is identified by the simulation. NE evaluates the relative errors in the total area of flood inundation extents. 
Acknowledgements. The authors would like to express deep gratitude to the Royal Irrigation Department (RID) and Thai Meteorological Department (TMD) for providing us with observation records. The discussions with the JICA project team on a Comprehensive Flood Management Plan for the Chao Phraya River Basin, Anurak Sriariyawat at Chulalongkorn University in Thailand, Daisuke Komori at Tohoku University and Taichi Tebakari at Toyama Prefectural University helped us understand the 2011 flood hazards in Thailand. The authors would like to thank Susumu Fujioka, Tomoki Ushiyama, Atsuhiro Yorozuya and Kuniyoshi Takeuchi at ICHARM for their support during the post-flood data correction and analysis. This research was funded by MEXT KAKENHI (Grant-in-Aid for Scientific Research (C), 24560633) and grants supported by the Public Works Research Institute of Japan.

Edited by: B. Merz

Reviewed by: two anonymous referees

\section{References}

Apel, H., Thieken, A. H., Merz, B., and Blöschl, G.: A probabilistic modelling system for assessing flood risks, Nat. Hazards, 38, 79_ 100, doi:10.1007/s11069-005-8603-7, 2006.

Cash, J. R. and Karp, A. H.: A variable order Runge-Kutta method for initial value problems with rapidly varying right-hand sides, ACM T. Math. Software, 16, 201-222, 1990.

Coe, M. T., Costa, M. H., and Howard, E. A.: Simulating the surface waters of the Amazon River basin: impacts of new river geomorphic and flow parameterizations, Hydrol. Process., 22, 25422553, doi:10.1002/hyp.6850, 2008.

Dooge, J. C. I.: Sensitivity of runoff to climate change: a Hortonian approach, B. Am. Meteorol. Soc., 73, 2013-2024, 1992.

Dooge, J. C. I., Bruen, M., and Parmentier, B.: A simple model for estimating the sensitivity of runoff to long-term changes in precipitation without a change in vegetation, Adv. Water Resour., 23, 153-163, doi:10.1016/S0309-1708(99)00019-6, 1999.

Dutta, D., Herath, S., and Musiake, K.: A mathematical model for flood loss estimation, J. Hydrol., 227, 24-49, doi:10.1016/S0022-1694(03)00084-2, 2003.

Iwasa, Y. and Inoue, K.: Mathematical simulation of channel and overland flood flows in view of flood disaster engineering, Journal of Natural Disaster Science, 4, 1-30, 1982.

JICA (Japan International Cooperation Agency): Project for the comprehensive flood management plan for the Chao Phraya River Basin, Final Report, 1, 69 pp., JICA, 2013.

Kim, W., Komori, D., Cho, J., Kanae, S., and Oki, T.: Longterm analysis of evapotranspiration over a diverse land use area in northern Thailand, Hydrological Research Letters, 8, 45-50, doi:10.3178/hrl.8.45, 2014.

Komori, D., Nakamura, S., Kiguchi, M., Nishijima, A., Yamazaki, D., Suzuki, S., Kawasaki, A., Oki, K., and Oki, T.: Characteristics of the 2011 Chao Phraya River flood in central Thailand, Hydrological Research Letters, 6, 41-46, doi:10.3178/HRL.6.41, 2012

Komori, D., Mateo, C. M., Saya, A., Nakamura, S., Kiguchi, M., Klinkhachorn, P., Sukhapunnaphan, T., Champathong, A., Takeya, K., and Oki, T.: Application of the probability evaluation for the seasonal reservoir operation on flood mitigation and water supply in the Chao Phraya River watershed, Thailand, Journal of Disaster Research, 8, 432-446, 2013.

Kotsuki, S. and Tanaka, K.: Impacts of mid-rainy season rainfall on runoff into the Chao Phraya River, Thailand, Journal of Disaster Research, 8, 397-405, 2013.

Lehner, B., Verdin, K., and Jarvis, A.: New global hydrography derived from spaceborne elevation data, EOS T. Am. Geophys. Un., 89, 93-94, 2008.

Masutani, K., Akai, K., and Magome, J.: A new scaling algorithm of gridded river networks, Journal of Japan Society of Hydrology and Water Resources, 19, 139-150, 2006 (in Japanese with English abstract).

Mizukami, N., Clark, M. P., Slater, A. G., Brekke, L. D., Elsner, M. M., Arnold, J. R., and Gangopadhyay, S.: Hydrologic implications of different large-scale meteorological model forcing datasets in mountainous regions, J. Hydrometeorol., 15, 474488, doi:10.1175/JHM-D-13-036.1, 2014.

Okada, T., McAneney, K. J., and Chen, K.: Estimating insured residential losses from large flood scenarios on the Tone River, Japan - a data integration approach, Nat. Hazards Earth Syst. Sci., 11, 3373-3382, doi:10.5194/nhess-11-3373-2011, 2011.

Oldenborgh, G. J. V., Urk, A. V., and Allen, M. R.: The absence of a role of climate change in the 2011 Thailand floods, B. Am. Meteorol. Soc., 93, 1047-1049, doi:10.1175/BAMS-D-12-00021.1, 2012.

Press, W. H., Teukolsky, S. A., Vetterling, W. T., and Flannery, B. P.: Adaptive stepsize control for Runge-Kutta, Numerical Recipes in Fortran 77: The Art of Scientific Computing, 2nd Edn., Cambridge University Press, New York, USA, 708-716, 1992.

Sankarasubramanian, A., Vogel, R. M., and Limbrunner, J. F.: Climate elasticity of streamflow in the United States, Water Resour. Res., 37, 1771-1781, doi:10.1029/2000WR900330, 2001.

Sayama, T., Ozawa, G., Kawakami, T., Nabesaka, S., and Fukami, K.: Rainfall-runoff-inundation analysis of the 2010 Pakistan flood in the Kabul River basin, Hydrolog. Sci. J., 57, 298-312, doi:10.1080/02626667.2011.644245, 2012.

Sayama, T., Tatebe, Y., and Tanaka, S.: An emergency response-type rainfall-runoff-inundation simulation for 2011 Thailand floods, Journal of Flood Risk Management, doi:10.1111/jfr3.12147, online first, 2015.

Schaake, J. C.: From climate to flow, in: Climate Change and US Water Resources, edited by: Waggoner, P. E., John Wiley, New York, 177-206, 1990.

Tanaka, K., Takizawa, H., Tanaka, N., Kosaka, I., Yoshifuji, N., Tantasirin, C., Piman, S., Suzuki, M., and Tangtham, N.: Transpiration peak over a hill evergreen forest in northern Thailand in the late dry season: Assessing the seasonal changes in evapotranspiration using a multilayer model, J. Geophys. Res., 108, 4533, doi:10.1029/2002JD003028, 2003.

Tanaka, N., Kume, T., Yoshifuji, N., Tanaka, K., Takizawa, H., Shiraki, K., Tantasirin, C., Tangtham, N., and Suzuki, M.: A review of evapotranspiration estimates from tropical forests in Thailand and adjacent regions, Agr. Forest Meteorol., 148, 807-819, 2008.

Tarekegn, T. and Sayama, T.: Correction of SRTM DEM Artefacts by Fourier Transform for Flood Inundation Modeling, Journal of Japan Society of Civil Engineers, Ser B1, Hydraulic Engineering, 69, I_193-I_198, 2013. 
Tchuente, A. M. T., Roujean, J. L., and Faroux, S.: ECOCLIMAPII: An ecosystem classification and land surface parameters database of Western Africa at $1 \mathrm{~km}$ resolution for the African Monsoon Multidisciplinary Analysis (AMMA) project, Remote Sens. Environ., 114, 961-976, doi:10.1016/j.rse.2009.12.008, 2010.

Uppala, S. M., Kållberg, P. W., Simmons, A. J., Andrae, U., Bechtold, V. D. C., Fiorino, M., Gibson, J. K., Haseler, J., Hernandez, A., Kelly, G. A., Li, X., Onogi, K., Saarinen, S., Sokka, N., Allan, R. P., Andersson, E., Arpe, K., Balmaseda, M. A., Beljaars, A. C. M., Berg, L. V. D., Bidlot, J., Bormann, N., Caires, S., Chevallier, F., Dethof, A., Dragosavac, M., Fisher, M., Fuentes, M., Hagemann, S., Hólm, E., Hoskins, B. J., Isaksen, L., Janssen, P. A. E. M., Jenne, R., Mcnally, A. P., Mahfouf, J.-F., Morcrette, J.-J., Rayner, N. A., Saunders, R. W., Simon, P., Sterl, A., Trenberth, K. E., Untch, A., Vasiljevic, D., Viterbo, P., and Woollen, J.: The ERA-40 re-analysis, Q. J. Roy. Meteor. Soc., 131, 29613012, doi:10.1256/qj.04.176, 2005.
Vano, J. A. and Lettenmaier, D. P.: A sensitivity-based approach to evaluating future changes in Colorado River discharge, Climatic Change, 122, 621-634, doi:10.1007/s10584-013-1023-x, 2014.

Vano, J. A., Das, T., and Lettenmaier, D. P.: Hydrologic sensitivities of Colorado River runoff to changes in precipitation and temperature, J. Hydrometeorol., 13, 932-949, doi:10.1175/JHM-D-11069.1, 2012.

Vongvisessomjai, S.: Flood mitigation master plan for Chao Phraya Delta, 4 INWEPF Steering Meeting and Symposium, Bangkok, Thailand, 5-7 July 2007, 1-04, 2007.

The World Bank: Thai Flood 2011, Rapid Assessment for Resilient Recovery and Reconstruction Planning, World Bank, Bangkok, 2012. 